\title{
診断・治療に腹腔鏡が有用であった付属器膿瘍の二例 \\ Laparoscopic diagnosis and treatment of adnexal abscess: a report of two cases
}

\author{
関東受災病院
}

袖本武男、中尾美木、細川有美、橋本耕一、香川秀之

\section{緒言}

付属器膿瘍は急性骨盤内感染症の7〜 16\%に合 併すると言われている1”。付属器膿瘍が破裂した 場合には緊急に開腹手術が必要になるが、未破裂 の付属器膿瘍に対しては抗生剤による治療を行 い、無効例に対して外科的介入を行うというのが

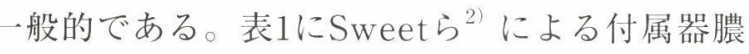
瘍の管理のアルゴリズムを示す。付属器膿瘍の患 者に対して抗生物質による治療を行い、48～72時 間で効果が確認されなければ外科的介入を行うと されている。外科的介入には腹腔鏡、経胵的穿刺、 ドレナージ、開腹術がある。外科的介入は従来開 腹術で行われることが多かったが、近年腹腔鏡の 有用性が報告されている ${ }^{3-6)}$ 。今回、診断・治療 に腹腔鏡が有用であった二症例を経験したので若 干の文献的考察を加えて報告する。

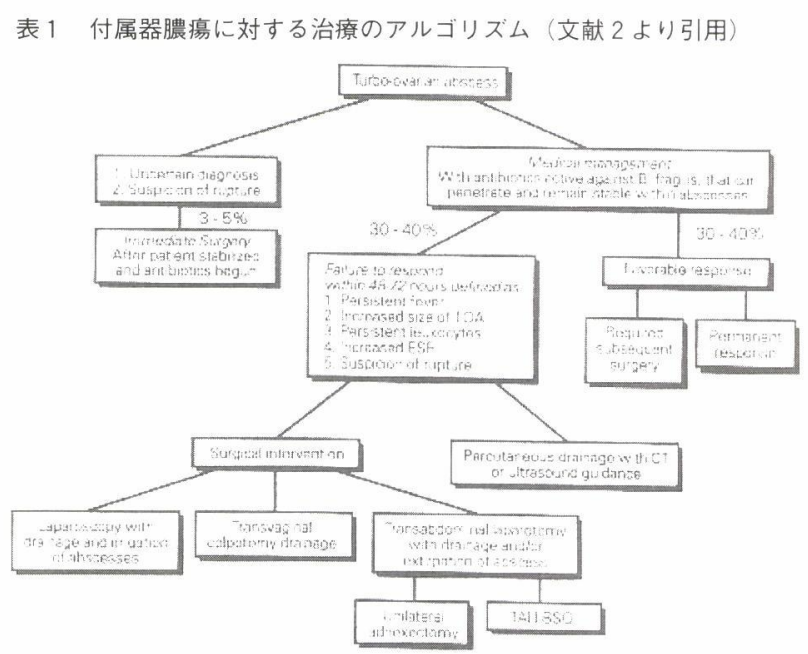

症例 1

患者: 29歳、未経妊

主訴：下腹部痛
現病歴： 1 年前より他院にて卵巣囊胞を指摘され ていた。下腹部痛を主訴に当院内科を受診し、血 液検查で炎症反応を認めたため抗生物質を経口投 与された。症状が改善しないため、1 週間後の平 成17年 1 月17日当科を紹介受診した。

身体所胃：体温 $37.7^{\circ} \mathrm{C}$ 、脈拍 $99 /$ 分、血圧 $122 / 82$ 、 腹部は平坦、右下腹部に圧痛あり、筋性防御あり。 内診所見では带下は白色、中等量、子宮澒部・多 グラス窩に压痛を認めず、子宮は正常大、やや可 動性不良、軽度の圧痛あり、右付属器に裹胞性腫 瘤を触知し、この部に圧痛を認めた。

血液検查所見：WBC $12500 / \mathrm{mm}^{3}$, $\mathrm{Hgb} 13.4 \mathrm{~g} / \mathrm{dl}$, Het $40.7 \%$, Plt $360 \times 10^{3} / \mathrm{mm}^{3}$, CRP $3.17 \mathrm{mg} / \mathrm{dl}$, クラミジア抗体 $\operatorname{Ig} A(-), \operatorname{IgG}(-)$

腟分泌物培養検查：常在菌のみ

経䐋超音波検査所見：左卵宩に径 $5 \mathrm{~cm}$ の囊胞を 認めた。

MRI検查所見 (図 1 ) : 子宮の左上前方に $5 \mathrm{~cm}$ 程 度の囊胞性腫瘤が見られ、内腔はT1強調画像で inhomogenous な淡いhigh intensityを示し、T2 強調画像でlow intensityの部分とhigh intensity の部分がfluid-fluid levelを形成している。子宮内 膜症性囊胞が疑われた。

図 1 症例 1 のMRI所見 左: T1強調矢状断像

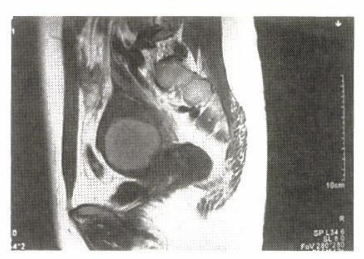
右：T2強調矢状断像

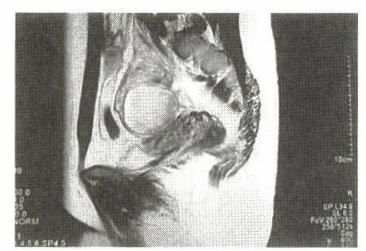

入院後経過: 子宮内膜症性卵巣囊胞及び骨盤腹膜 炎の診断でCAZ $2 \mathrm{~g} /$ 日, CLDM1200mg/日併用 による治療を開始した。しかし自覚症状・他覚所 
見ともに改善が見られず、血液検查でも炎症所見 はWBC $12800 / \mathrm{mm}^{3}$, CRP $8.65 \mathrm{mg} / \mathrm{dl}$ と增悪傾向 を示していたため、入院 8 日目に診断およびドレ ナージ目的で腹腔鏡下手術を行う方針とした。

手術所見（図 2 ）：腹腔鏡下に観察したところ少 量の腹水を認め、子宮と直腸、左卵巣囊胞 (A) と左卵管・子宮・S状結腸に癒着を認めた。左卵 巣囊胞内容液を穿刺・吸引したところ内容液は膿 性であった（B）。この所見より左卵巣膿瘍と診 断した。囊胞内腔を焼灼 (C) 後、生理的食塩水 にて腹腔内を洗浄し、ダグラス窩にドレーンを留 置して手術を終了した。

\section{図 2 症例 1 の手術所見}
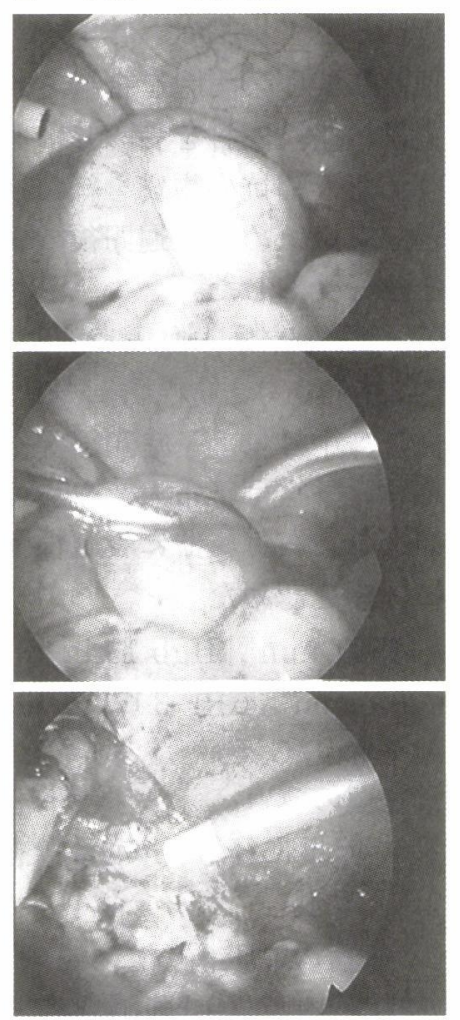

C. 囊胞内腔を焼灼

術後経過：自覚症状・炎症所見ともに速やかに改 善した。術後 3 日目にドレーンを抜去し、術後 7 日目まで抗生物質の投与を行った。術後経過は良 好で 9 日目に退院となった。その後の外来通院で は自覚症状・他覚所見ともに異常所見を認めてい ない。

症例 2

患者: 29歳、未経妊

現病歴：3日前から続く下腹部痛を主訴に平成 17 年1月14日当院外科を受診した。虫垂炎等の外科 的疾患は否定的であるとのことで、当科紹介受診 となった。

身体所見：体温 $37.5^{\circ} \mathrm{C}$ 脈拍 $90 /$ 分 血圧 $107 / 59$ 、
腹部は平坦で下腹部全体に压痛と筋性防御を認め た。内診所見では带下は白色、中等量、子宮頚部 及びダグラス窩の圧痛が著明で、子宮・付属器は 筋性防御が強いために触知不能であった。

血液検査所胃：WBC $13800 / \mathrm{mm}^{3}, \mathrm{Hgb} 14.1 \mathrm{~g} / \mathrm{dl}$, Hct $41.4 \%$, Plt $385 \times 10^{3} / \mathrm{mm}^{3}$, CRP $20.58 \mathrm{mg} / \mathrm{dl}$ 子宮頝部クラミジア抗原：陰性

胵分泌物培養検査：常在菌のみ

経腟超音波検査所見: 左卵巣に径 $4 \mathrm{~cm}$ の囊胞を 認める他ダグラス窩に液体貯留を認めた。

MRI検査所見 (図 3)：子宮の左側に径 $4 \mathrm{~cm}$ の囊 胞性腫瘤を認め、T2強調画像でgradationがあり、 T1強調画像でhigh intensityという所見より子宮 内膜症性卵巣囊胞が疑われた。ダグラス㸗には液 体貯留を認めた。
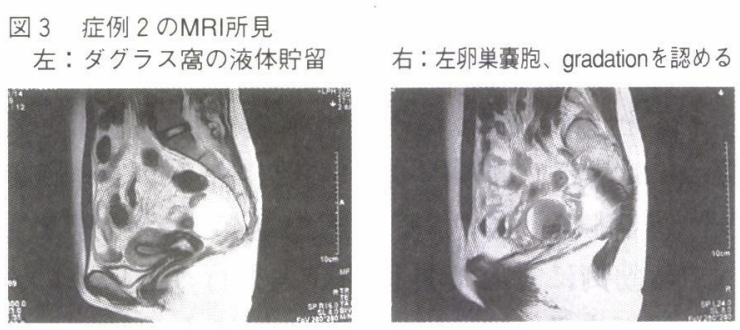

初診後の経過: 子宮内膜症性卵巣囊胞及び骨盤腹 膜炎と診断した。入院・加療を锥めたが、本人・ 家族の同意が得られなかった。このため外来にて 経口抗生物質投与を行う方針とした。炎症所見・ 自覚症状は一旦改善したが、その後は不変となっ たため、初診から 2 週間後に入院となった。

入院時血液検查所見 : WBC $15700 / \mathrm{mm}^{3}, \mathrm{Hgb}$ $11.8 \mathrm{~g} / \mathrm{dl}$, Hct $36.0 \%$, Plt $538 \times 10^{3} / \mathrm{mm}^{3}$, CRP $9.91 \mathrm{mg} / \mathrm{dl}$

入院後経過：CAZ $2 \mathrm{~g} /$ 日・CLDM1200mg/日を 3 日間投与したが、血液検査所見・診察所見とも に改善を認めなかったため、入院 4 日目に診断お よびドレナージ目的で腹腔鏡下手術を行う方針と した。

手術所見 (図 4)：大網・小腸・結腸が壁側腹膜 と広範囲で㦄着していた (A)。左卵巣囊胞壁を 切開したが、内容液よりチョコレート襄胞と考え られ (B)、この部位の感染は否定的であった。 右卵管が腫大し先端がダグラス窩に落ち込んで強 く癒着していた $(\mathrm{C})$ 。石卵管膿瘍が疑われたた め、周囲との癒着を剥離した後に切開・排膿を行 つた（D）。生理的食塩水にて腹腔内を洗浄し、 ダグラス窩にドレーンを留置して手術を終了し た。 


\section{術後経過}

図 4 症例 2 の手術所見

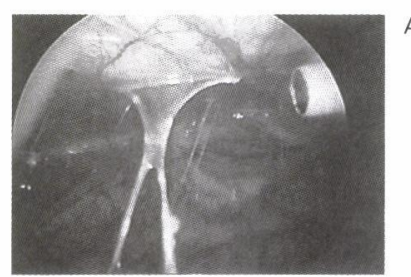

大網・小腸・結腸が壁側 腹膜と広範囲に癒着
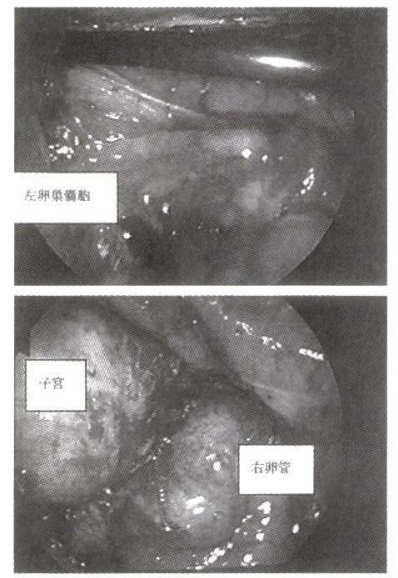

C. 右卵管が腫大し先端がダ グラス窩に落ち込んで強 く癒着。

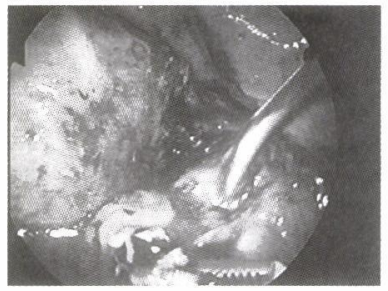

D. 右卵管膿瘍と診断、切 開・排囊。

術後 3 日目にドレーンを抜去した。術後 4 日且 まで抗生物質の静注投与を継続し、その後経口投 与とした。経過良好で術後 8 日目に退院となった。 その後の外来通院でも自覚症状・他覚所見ともに 異常を認めていない。

\section{考察}

今回経験した二症例はいずれも子宮内膜症性卵 巣囊胞掞よび骨盤腹膜炎という術前診断であった が、腹腔鏡により感染巣が特定され、卵巣膿湯・ 卵管膿瘍とそれぞれ診断された。症例 1 は卵巣子 宮内膜症性囊胞に上行性の感染を伴って膿瘍化し たもの、症例 2 は上行性に波及した感染が骨盤腹 膜炎を来たし、卵管の癒着を生じその上で感染が 進行したために卵管瘤膿症を生じたと考えられ た。二例ともドレナージ術を施行し、術後経過は 良好であった。

付属器膿瘍に対する腹腔鏡下ドレナージの有効 性については複数の報告がなされている Henry-Suchet ${ }^{4)}$ は80例に腹腔鏡下ドレナージを 施行し、72例 $(90 \%)$ が治癒したとその有効性を

報告している。Buchweitzら ${ }^{5)}$ は25例の付属器膿 瘍に対して腹腔鏡下ドレナージを行い、1 例の骨 盤痛による再入院を除く 24 例は治癒と判断された としている。Buchweitzら ${ }^{5}$ は腹腔鏡下ドレナー ジ例と腹腔鏡下に摘出手術を行った 35 例との比較 についても報告している。ドレナージ例では上記 のように 1 例が再入院したが、それ以外の術中・ 術後合併症は見られなかった。これに対し摘出術 例では腸管損傷による開腹手術移行例が 1 例、腸 管の漿膜損傷が 4 例、血管損傷が 2 例、大網損傷 が 2 例に発生し、計 9 例に術中合併症を認めた。 術後合併症も 9 例に見られ、その内訳は $38^{\circ} \mathrm{C}$ 以上 の発熱例が 1 例、腸閉塞 2 例、下肢静脈血栓が 2 例、骨盤痛による再入院 4 例であった。このこと から患者の年齢や妊娠についての希望に関わらず 合併症のリスクを減らすために、付属器膿瘍に対 して腹腔鏡下手術を行う際には臓器温存手術を選 択すべきであると結論づけている。ドレナージ (癒着剥離を含む) を開腹術で行った場合と腹腔 鏡下に行った場合の比較はYangら が行なって いる。入院期間は開腹例・腹腔鏡例でそれぞれ $8.29 \pm 2.59$ 日、 $5.37 \pm 1.38$ 日で腹腔鏡例の方が有意 に（p=0.0001）短かった。術後発熱期間は $39.46 \pm 17.47$ 時間と25.79 \pm 11.45 時間で腹腔鏡例の 方が有意に（ $\mathrm{p}=0.003 ）$ 短かった。また術中の他 臓器損傷・術後創部感染などの合併症例がそれぞ れ 12 例 $(32.4 \%)$ と 2 例 $(10.5 \%)$ で統計学的有 意差はないものの腹腔鏡例で合併症例が少ない傾 向にあったと報告している。

付属器膿瘍に関して急性期の治療とともに問題 となるのが、その後の妊㝋性である。腹腔鏡下ド レナージを行った付属器膿瘍症例の妊㝋性につい ての報告は未だ少ないが、Raigaら ${ }^{6)}$ は腹腔鏡下 ドレナージの 3 〜 6 月後に行ったsecond-look laparoscopyの結果について報告している。35例 にsecond-look laparoscopyを行ったが、妊孕性回 復のためには全例で癒着剥離術が必要であり、17 例には卵管形成術も同時に施行された。その結果、 妊娠を希望した19例中12例（63\%）は自然妊娠し、 体外受精を勧めた 6 例中 3 例で体外受精が行わ れ、2 例が妊娠したとしている。そしてこの結果 から妊娠を希望する患者ではsecond-look laparoscopyが不可欠であると述べている。 Henry-Suchet ${ }^{4)}$ は発症から 3 週間以内に腹腔鏡 下ドレナージを施行した21例に対して行った second-look laparoscopyでは18例（85\%）が全く 正常な骨盤内所見であったと報告し、早期に治療 
を行えば癒着症例は少ないとしている。今回の二 症例はいずれも治療時に挙児希望がなかったた め、 second-look laparoscopyについては今後の状 況により行う可能性があるとの説明のみにとどめ たが、挙児希望がある場合にはドレナージ術を行 った後にsecond-look laparoscopyを行って付属器 の状態を評価すべきであると考える。付属器膿瘍 に対して腹腔鏡下ドレナージを行った症例の妊孕 性について症例を蓄積して検討する必要がある。

付属器膿瘍の治療において、低侵襲で妊孕性温 存という観点からも腹腔鏡下ドレナージが開腹手 術・摘出手術と比較してメリットが大きいと考え られるが、より低侵襲な方法として超音波ガイド 下のドレナージについての早期の治療効果が報告 されている ${ }^{8-10)}$ 。しかしながら治療後の妊孕性等 の長期予後については殆ど報告されておらず、今 後の検討が待たれる。また今回の 2 症例のように 超音波検査では感染巣の同定が困難な例では、腹 腔鏡による診断・治療が必要となると考える。

\section{まとめ}

1. 付属器膿瘍二例について腹腔鏡下に診断しド レナージ術を施行した。

2. 付属器膿瘍の診断・治療において腹腔鏡が有 用であると考えられる。

本論文の要旨は第 45 回日本産婦人科内視鏡学会 （宝塚）にて発表した。

\section{引用文献}

1 ) Sweet RL,Gibbs RS: Infeciton Disease of the Female Genital Tract, 197. Lippincott Williams \& Willkins,Philladelphia.2002

2 ) Sweet RL,Gibbs RS: Infeciton Disease of the Female Genital Tract, 197. Lippincott Williams \& Willkins,Philladelphia.2002

3 ) Aducci JE. et al : Laparoscopy in the Diagnosis and Pelvic Inflammatory Disease with Abscess Formation. Int Surg 66:359, 1981

4 ) Henry-Suchet J:Laparoscopic Treatment of Tuboovarian Abscess:Thirty Year's Experience.J Am Assoc Gynecolo Laparocc 9:235, 2002

5 ) Buchweitz O, et al: Laparoscopic management of tubo-ovarian abscess:Retrospective analysis of 60 cases . Sug Endosc 10:948, 2000

6) Raiga J. et al : Laparoscopic management of adnexal abscess : consequences for fertility. Firtil and Steril 66(5):712,1996

7 ) Yang CC, et al:Advantages of Open Laparoscopic Sugery over Explolatory Laparotomy in Patients with Tubo-ovarian Abscess. J Am Assoc Gynecol Laparosc 9:327,2002

8 ) Shulman A, et al:Pecutaneaus catheter drainage of tubo-ovarian abscess. Obstet Gynecol80:555,1992

9 ) Perez-Medina T, Hurtas MA, Bajo JM:Early ultrasound-guided transbaginal drainage of tuboovarian abscess : a randomized study.Ultrasound Obstet Gynecol 7:435,1996

10) Capsi B, et al:Sonographically guided aspiration: an alternative therapy for tubo-ovarian abscess. Ultrasound Obstet Gynecol 7:439,1996 